\title{
SULINA (ROMANIA) - EUROPEAN MODEL OF ETHNIC AND RELIGIOUS COHABITATION
}

DOI: http://dx.doi.org/10.18509/GBP.2015.39

UDC:316.723-021.463(498)

\author{
Prof. Dr. Gheorghe Romanescu ${ }^{1}$ \\ Prof. Dr. Vasile Efros ${ }^{2}$ \\ ${ }^{1}$ Alexandru Ioan Cuza University of Iasi, Faculty of Geography and Geology, Department of \\ Geography, Bd. Carol I 20A, 700505, Iasi, Romania \\ ${ }^{2}$ Stefan cel Mare University of Suceava, Faculty of History and Geography, Department of \\ Geography, Universitatii 1, Suceava, Romania
}

\begin{abstract}
The Danube mouths have been submitted to the European Danube Commission and the Sulina town became the headquarter. Under these circumstances, Sulina acquired the status of porto franco and it flourished. This led to one of the most interesting ethnic and religious mosaics in Europe. At the end of the nineteenth century, there were 22 confirmed nationalities, among which the dominant ones were the Greeks, the Romanians, the Armenians, the Russians, the Turks, etc. The ethnic diversity also determined the emergence of highly diverse religious confessions: Orthodox, Old Rite Orthodox, Catholic, Muslim, Protestant, etc. The freedom of commerce and the interest for money made this ethnic and religious diversity free of conflicts. From this perspective, Sulina represents the European model of confessional cohabitation. The dissolution of the European Danube Commission (1938) and the instauration of communism in Romania led to the economic fall of the town, to its depopulation and to the disappearance of several places of worship: an Anglican church, the mosques and the synagogue. The testimony of ethnic and confessional diversity is represented by the common cemetery, where there are delimited areas belonging to the Romanian, Greek, Jewish, Russian, Turk, Italian communities and to the European Danube Commission.
\end{abstract}

KEYWORDS: Religious confessions, Cosmopolitism, Danube Delta, Demography, Porto franco.

\section{INTRODUCTION}

Europe is the continent where migrations have created an ethnic mosaic in most countries. Romania is not an exception from this rule because it is situated at the crossroads of the great European roads. For this reason, on the entire Romanian territory, there are human settlements that indicate the origin of the European or Asian population. The most cosmopolitan region of Romania is Dobrudja where - alongside Romanians - have been living Lippovan Russians, Ukrainians, Turks, Tatars, Greeks, Jews, Italians, Germans, etc. From this perspective, the European model can be represented by the Sulina town, situated at the Danube mouths, in an area of great commercial circulation until the outbreak of the Second World War. At the same time, Sulina acquires the atmosphere of the Balkan environment, a melting pot between the Orient and the Occident. The demographic, social and economic behaviour is specific to port cities. On a general level, the demographic and religious studies underline the importance of the political and economic factor in the emancipation of an area [1,2]. 
Dobrudja - including the Danube Delta - caught early on the attention of the great colonial powers. The first Greek colonies appeared in the $8^{\text {th }}-7^{\text {th }}$ centuries BCE: Tomis, Calatis, Histria, Orgame (Argamum), etc. The ancient Greeks describe the Danube mouths as occupied by the Peucini (Strabo, Herodotus, etc) (Author 1995, 1999, 2004, 2005, 2013a, 2013b, 2014; Author and Author 2010). The Romans arrived to Dobrudja 100 years before the conquest of Dacia. The cities on the Danubian limes defended the realm between the Danube and Pontus Euxinus: Carsium, Capidava, Troesmis, Dinogetia, Noviodunum, Salsovia, Halmyris, etc. The troubled history of Dobrudja and of the Danube mouths has imposed a systematic study, approached by both foreigners and Romanians [3-7]. This study underlines the existence of a traditional ethnic and religious cohabitation, within a region disputed by the neighbouring powers: Romania, the Ottoman Empire, Russia and Bulgaria.

\section{GEOGRAPHICAL LOCATION}

Sulina is the only town within the Danube Delta. It is situated at the mouth of the Sulina arm. The distance to the Black Sea is $3 \mathrm{~km}$. Along the arm - that goes into the sea through the jetties - it is situated $10 \mathrm{~km}$ away. It encompasses $14 \mathrm{~km}^{2}$ and it is crossed by the parallel of $45^{\circ} 9^{\prime} 34^{\prime \prime} \mathrm{N}$ and by the meridian of $29^{\circ} 39^{\prime} 10^{\prime \prime} \mathrm{E}$ (Fig. 1).

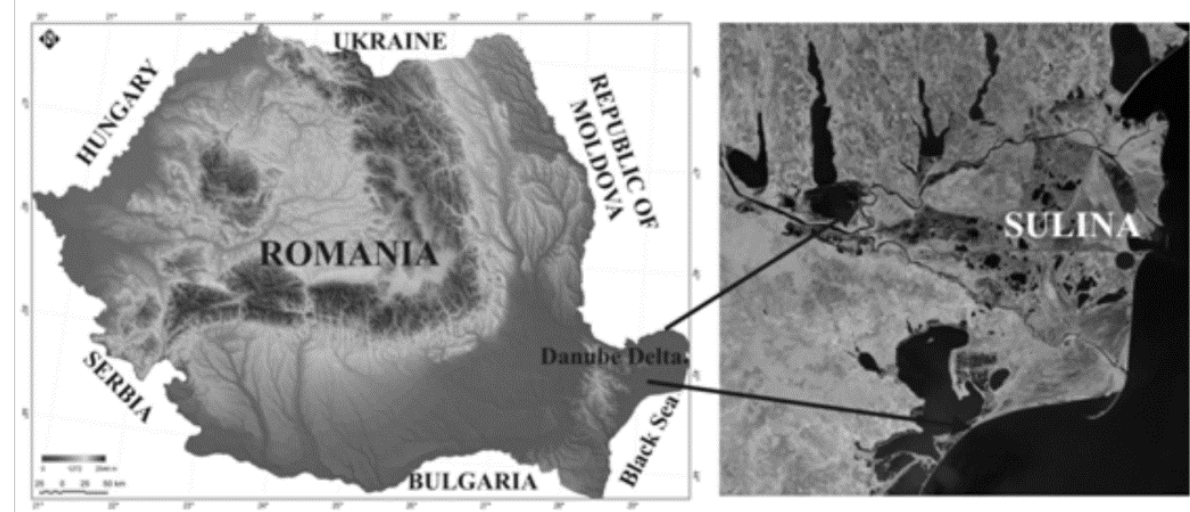

Fig. 1 Geographic location of the Sulina town within Romania and the Danube Delta

\section{MATERIALS AND METHODS}

The scientific literature (human geography, demography, theology, sociology, economy, commercial navigation, etc) on the Sulina town is extremely rich because it makes a special reference to the Danube Delta. Most materials on the history of the town, on demographic and economic characteristics were taken from the scientific literature, from censuses and from the Sulina Town Hall. The documents on the history of the European Danube Commission and of the capacity of merchandise handling were provided by the Fluvial Administration of Lower Danube (headquarter in Galați).

The data on the population of the Sulina town and of the Danube Delta were taken from the National Censuses published in 1912, 1930, 1956, 1969, 1980, 1994, 2003 and 2012 [8-10], as well as from the monographs Commission Européenne du Danube (1931) [11] and Chestiunea Dunarei (1933) [12]. The field research concerned the placement of religious objectives (churches and cemetery) and the collection of data from priests and believers. The entire activity was carried out in the summer of 2013. The entire graphic material belongs to the authors. 


\section{RESULTS}

The first mention in documents of the Sulina town dates to the reign of the Byzantine Emperor Constantine Porphyrogenitus (AD 913-959), in the documents entitled "De administrando Imperi". Anna Komnene (end of the eleventh - beginning of the twelfth century) mentions the Selinas (Solina) town as being situated at the mouth of the Calonstoma arm. It became a Genovese port in 1318 and a Turkish one in 1469. Sulina as fluvial-maritime port - is mentioned in the Russo-Austrian convention of Saint Petersburg (1840), when the bases of free navigation on the Danube were established.

The economic importance of Sulina has increased by the constitution of the European Danube Commission following the Treaty of Paris, of 1856 (C.E.D.). This commission was founded at the request of the great European powers: England, France, Austria, Prussia (Germany), Sardinia (Italy), Russia and Turkey (that possessed Dobrudja and the Danube mouths); Romania was also invited as observer. At the same time, Sulina acquired the status of free port (porto franco) because it was neutral in times of war and peace. It is worth mentioning that - because of this status and the localization of the official administration of the ECD at Sulina - the concept of United Europe was developed "officially" for the first time, by the expression of tolerance and multiethnic cohabitation.

The status of commercial town and important import-export ramp for Romania and for the countries through which Danube flowed led to the constitution, in the Sulina town until the dissolution of the European Danube Commission (1938) - of nine consular institutions: the Austrian consulate, the English, German, Italian, Danish, Dutch, Greek, Russian and Turkish vice-consulates. Belgium had a consular agency. The most important shipping companies in Europe had offices at Sulina: Lloyd Austria Society (Austria), Deutsch Levante Linie - D.L.L. (Germany), Egeo (Greece), Johnston Line (England), Florio et Rubatino (Italia), Westcott Linea (Belgium), Messagerie Maritime (France), Serviciul Maritim Roman. For all officials, documents were issued in French and English; the communication language was Greek (the most numerous population was Greek). The newspapers "Gazeta Sulinei", "Curierul Sulinei", "Delta Sulinei and "Analele Sulinei" were edited in several languages. The outbreak of the Second World War (1939) led to the loss of neutrality and to the withdrawal of consular institutions. This was also the beginning of the town's gradual but sure fall.

The economic development and the flourishing commerce of the port attracted a great number of inhabitants from all European countries. At the end of the nineteenth century and the beginning of the twentieth century, the most numerous inhabitants were the Greeks, followed by the Romanians, the Russians, the Armenians, the Turks, etc. In the Sulina town, there were 22 nationalities comprising 4,889 inhabitants (Table 1). For all the localities within the Danube Delta, the situation was different only concerning certain ethnic groups (Table 2).

Table 1 Population of the Sulina town at the census of 1912

\begin{tabular}{cccc}
\hline No. & Nationalities & No. of inhabitants & $\%$ \\
\hline 1 & Greeks & 2056 & 42.05 \\
2 & Romanians & 803 & 16.42 \\
3 & Russians & 546 & 11.16 \\
4 & Armenians & 444 & 09.08 \\
5 & Turks & 268 & 05.39 \\
6 & Austro-Hungarians & 211 & 04.31 \\
7 & Jews & 173 & 03.53 \\
8 & Albanians & 117 & 02.39
\end{tabular}




\begin{tabular}{cccc}
9 & Germans & 49 & 01.00 \\
10 & Italians & 45 & 0.92 \\
11 & Bulgarians & 35 & 0.71 \\
12 & English & 24 & 0.49 \\
13 & Tatars & 22 & 0.44 \\
14 & Montenegrins & 22 & 0.44 \\
15 & Serbians & 21 & 0.42 \\
16 & Polish & 17 & 0.34 \\
17 & French & 11 & 0.22 \\
18 & Lippovans & 7 & 0.14 \\
19 & Danish & 6 & 0.12 \\
20 & Gagauzians & 5 & 0.10 \\
21 & Indians & 4 & 0.08 \\
22 & Egyptians & 3 & 0.06 \\
Total & & 4889 & 100.00 \\
\hline
\end{tabular}

Table 2 Total number of Danube Delta population by ethnic groups at the censuses of 1912, 1992 and 2002

\begin{tabular}{cccccccc}
\hline No. & Nationality & 1912 & $\begin{array}{c}\text { \% of the } \\
\text { total } \\
\text { population }\end{array}$ & 1992 & $\begin{array}{c}\text { \% of the } \\
\text { total } \\
\text { population }\end{array}$ & 2002 & $\begin{array}{c}\% \text { of the } \\
\text { total } \\
\text { population }\end{array}$ \\
\hline 1 & Romanian & 2652 & 21.70 & 11493 & 77.90 & 12666 & 86.88 \\
2 & Ukrainian & 4303 & 35.20 & 1329 & 9.01 & 299 & 2.05 \\
3 & Lippovan Russian & 1709 & 14.00 & 1666 & 11.27 & 1438 & 9.86 \\
4 & Greek & 2059 & 16.80 & 0 & 0 & 0 & 0 \\
5 & Turkish and Tartar & 290 & 2.50 & 13 & 0.09 & 17 & 0.12 \\
6 & Bulgarian & 103 & 0.80 & 7 & 0 & 0 & 0 \\
7 & Armenian & 444 & 3.60 & 2 & 0 & 0 & 0 \\
8 & German & 49 & 0.40 & 3 & 0 & 0 & 0 \\
9 & Austro-Hungarian & 211 & 1.70 & 11 & 0 & 0 & 0 \\
10 & Jewish & 173 & 1.40 & 0 & 0 & 0 & 0 \\
11 & Albanian & 117 & 1.00 & 0 & 0 & 0 & 0 \\
12 & Italian & 45 & 0.40 & 0 & 0 & 0 & 0 \\
13 & English & 24 & 0.20 & 0 & 0 & 0 & 0 \\
14 & Montenegro & 22 & 0.20 & 0 & 0 & 0 & 0 \\
15 & French & 11 & 0.10 & 0 & 0 & 0 & 0 \\
16 & Other nationalities & - & - & 35 & 0.39 & 33 & 0.23 \\
17 & Total & 12209 & - & 14754 & - & 14583 & - \\
\hline
\end{tabular}

The interwar period represented the climax of the development for the Sulina town. The maximum number of inhabitants was recorded in 1912 (7,347) (Fig. 2). In that year, in the town there were 1,200 dwellings, 154 shops, 3 mills, 70 small enterprises, one water factory, one electric factory, one telephone line, one modern road, $(8 \mathrm{~km})$ two hospitals. There were also a 300-seat theatre, two Greek schools, two Romanian schools, one German school, one Jewish school, several confessional schools, one middle school, one vocational school for girls and an English marine institute [12].

The local census conducted at the end of the nineteenth century indicates the same ethnic structure as in the year 1912 (Tables 1,3). The same structure - with slight alterations for some ethnic groups (English, Tatar, Turkish, French and Danish) - was maintained until 1930. At the censuses of 1930, 1956, 1992, 2002 and 2011, the Romanian ethnic group has been dominant, followed by the Russian, the Greek and the Turkish ones (Table 3). 
Table 3 Ethnic structure of the population of Sulina town

\begin{tabular}{|c|c|c|c|c|c|c|c|c|c|c|c|c|}
\hline \multirow{2}{*}{$\begin{array}{l}\text { Nationa } \\
\text { lity }\end{array}$} & \multirow{2}{*}{\multicolumn{2}{|c|}{$\begin{array}{l}\text { End. of } 19^{\text {th }} \\
\text { cen. } \\
\text { Stable } \% \text { of } \\
\text { popul the } \\
\text { ation total } \\
\text { popul } \\
\text { ation }\end{array}$}} & \multicolumn{2}{|c|}{1930} & \multicolumn{2}{|c|}{1956} & \multicolumn{2}{|c|}{1992} & \multicolumn{2}{|c|}{2002} & \multicolumn{2}{|c|}{2011} \\
\hline & & & $\begin{array}{c}\text { Stable } \\
\text { popul } \\
\text { ation }\end{array}$ & $\begin{array}{l}\% \text { of } \\
\text { the } \\
\text { total } \\
\text { popul } \\
\text { ation }\end{array}$ & $\begin{array}{l}\text { Stabl } \\
\text { e } \\
\text { popul } \\
\text { ation }\end{array}$ & $\begin{array}{l}\% \text { of } \\
\text { the } \\
\text { total } \\
\text { popul } \\
\text { ation }\end{array}$ & $\begin{array}{l}\text { Stabl } \\
\text { e } \\
\text { popul } \\
\text { ation }\end{array}$ & $\begin{array}{l}\% \text { of } \\
\text { the } \\
\text { total } \\
\text { popul } \\
\text { ation }\end{array}$ & $\begin{array}{l}\text { Stabl } \\
\text { e } \\
\text { popul } \\
\text { ation }\end{array}$ & $\begin{array}{l}\% \text { of } \\
\text { the } \\
\text { total } \\
\text { popul } \\
\text { ation }\end{array}$ & $\begin{array}{l}\text { Stabl } \\
\text { e } \\
\text { popul } \\
\text { ation }\end{array}$ & $\begin{array}{c}\% \\
\text { of the } \\
\text { total } \\
\text { popul } \\
\text { ation }\end{array}$ \\
\hline Greeks & 2056 & 41.9 & 1332 & 20.8 & 142 & 3.9 & 68 & 1.2 & 62 & 1.3 & 62 & 1.7 \\
\hline $\begin{array}{l}\text { Roman } \\
\text { ians }\end{array}$ & 803 & 16.3 & 3018 & 47.2 & 2554 & 70.5 & 4532 & 82.6 & 3955 & 86.0 & 3001 & 82.0 \\
\hline $\begin{array}{c}\text { Russia } \\
\text { ns }\end{array}$ & $601 *$ & 12.3 & $\begin{array}{c}1135 \\
*\end{array}$ & 17.7 & 837 & 23.1 & 695 & 12.7 & 504 & 10.9 & 362 & 9.9 \\
\hline $\begin{array}{c}\text { Armen } \\
\text { ians }\end{array}$ & 444 & 9.0 & 43 & 0.7 & 14 & 0.4 & & & & & & \\
\hline Turks & 268 & 5.4 & 189 & 2.9 & 24 & 0.7 & 11 & 0.2 & 7 & 0.2 & 4 & 0.1 \\
\hline $\begin{array}{c}\text { Ukrain } \\
\text { ians }\end{array}$ & & & & & 8 & 0.2 & 154 & 2.8 & 53 & 1.2 & 45 & 1.2 \\
\hline $\begin{array}{c}\text { Germa } \\
\text { ns }\end{array}$ & 49 & 1.0 & 62 & 1.0 & 13 & 0.3 & & & & & & \\
\hline $\begin{array}{c}\text { Austro } \\
-\end{array}$ & 211 & 4.3 & 26 & 0.4 & & & & & & & & \\
\hline $\begin{array}{l}\text { Hunga } \\
\text { rians }\end{array}$ & & & & & & & & & & & & \\
\hline Jews & 173 & 3.5 & 101 & 1.6 & & & & & & & & \\
\hline $\begin{array}{c}\text { Albani } \\
\text { ans }\end{array}$ & 117 & 2.4 & 6 & 0.1 & & & & & & & & \\
\hline Italians & 45 & 0.9 & & & & & & & & & & \\
\hline $\begin{array}{c}\text { Bulgar } \\
\text { ians }\end{array}$ & 35 & 0.7 & 30 & 0.5 & & & & & & & & \\
\hline $\begin{array}{c}\text { Englis } \\
\mathrm{h}\end{array}$ & 24 & 0.6 & & & & & & & & & & \\
\hline Tatars & 22 & 0.5 & & & & & & & & & & \\
\hline $\begin{array}{l}\text { Monte } \\
\text { negrins }\end{array}$ & 22 & 0.5 & & & & & & & & & & \\
\hline Polish & 17 & 0.4 & 30 & 0.5 & & & & & & & & \\
\hline French & 11 & 0.2 & & & & & & & & & & \\
\hline Danish & 6 & 0.1 & & & & & & & & & & \\
\hline $\begin{array}{c}\text { Serbia } \\
\text { n- } \\
\text { Croatia } \\
\text { ns }\end{array}$ & & & 210 & 3.3 & 7 & 0.2 & & & & & & \\
\hline $\begin{array}{l}\text { Other } \\
\text { ethnic } \\
\text { groups }\end{array}$ & & & 217 & 3.3 & 23 & 0.7 & 24 & 0.4 & 20 & 0.4 & 6 & 0.1 \\
\hline $\begin{array}{l}\text { Unavail } \\
\text { able } \\
\text { informa } \\
\text { tion }\end{array}$ & & & & & & & & & & & 183 & 5.0 \\
\hline Total & 4913 & 100 & 6399 & $\begin{array}{c}100 \\
\%\end{array}$ & 3622 & $\begin{array}{c}100 \\
\%\end{array}$ & 5484 & $\begin{array}{c}100 \\
\%\end{array}$ & 4601 & $\begin{array}{c}100 \\
\%\end{array}$ & 3663 & $\begin{array}{c}100 \\
\%\end{array}$ \\
\hline
\end{tabular}

During the entire period recorded, the Orthodox confession has been dominant, with a minimum $59.5 \%$ the end of the nineteenth century and a maximum $94.3 \%$ in the year 2002. The Old Rite confession is characteristic to the Slavic population (Russian Lippovans and Ukrainians) and it had a minimum $2.2 \%$ in 1930 and a maximum $27.5 \%$ 
in 1956 (Table 4). The Catholic confession had $7.4 \%$ in 1912 and a minimum $0.3 \%$ in the year 2011 (the year 1992 was not recorded). The Muslim religion had a maximum 8.3\% in the year 1912 and a minimum $0.1 \%$ in the year 2011. The other confessions, - Mosaic, Armenian, Hindi, etc - well represented at the end of the nineteenth century, have disappeared altogether at the latest censuses (Table 4).

Table 4 Confessional structure of the population of the Sulina town

\begin{tabular}{|c|c|c|c|c|c|c|c|c|c|c|c|c|}
\hline \multirow[t]{2}{*}{$\begin{array}{l}\text { Religi } \\
\text { on }\end{array}$} & \multicolumn{2}{|c|}{$\begin{array}{l}\text { End. of } 19^{\text {th }} \\
\text { cen. } *\end{array}$} & \multicolumn{2}{|c|}{1930} & \multicolumn{2}{|c|}{$1956^{*}$} & \multicolumn{2}{|c|}{1992} & \multicolumn{2}{|c|}{2002} & \multicolumn{2}{|c|}{2011} \\
\hline & $\begin{array}{l}\text { Stable } \\
\text { popul } \\
\text { ation }\end{array}$ & $\begin{array}{l}\% \text { of } \\
\text { the } \\
\text { total } \\
\text { popul } \\
\text { ation }\end{array}$ & $\begin{array}{l}\text { Stable } \\
\text { popula } \\
\text { tion }\end{array}$ & $\begin{array}{l}\% \text { of } \\
\text { the } \\
\text { total } \\
\text { popul } \\
\text { ation }\end{array}$ & $\begin{array}{l}\text { Stabl } \\
\text { e } \\
\text { popul } \\
\text { ation }\end{array}$ & $\begin{array}{l}\% \text { of } \\
\text { the } \\
\text { total } \\
\text { popul } \\
\text { ation }\end{array}$ & $\begin{array}{l}\text { Stabl } \\
\text { e } \\
\text { popul } \\
\text { ation }\end{array}$ & $\begin{array}{l}\% \text { of } \\
\text { the } \\
\text { total } \\
\text { popul } \\
\text { ation }\end{array}$ & $\begin{array}{l}\text { Stabl } \\
\text { e } \\
\text { popul } \\
\text { ation }\end{array}$ & $\begin{array}{l}\% \text { of } \\
\text { the } \\
\text { total } \\
\text { popul } \\
\text { ation }\end{array}$ & $\begin{array}{l}\text { Stabl } \\
\text { e } \\
\text { popul } \\
\text { ation }\end{array}$ & $\begin{array}{l}\% \text { of } \\
\text { the } \\
\text { total } \\
\text { popul } \\
\text { ation }\end{array}$ \\
\hline $\begin{array}{l}\text { Ortho } \\
\text { dox }\end{array}$ & 2921 & 59.5 & 5458 & 85.3 & 2554 & 70.5 & 4532 & 82.6 & 4340 & 94.3 & 3351 & 91.5 \\
\hline $\begin{array}{c}\text { Old } \\
\text { Rite } \\
\text { Christi } \\
\text { an } \\
\end{array}$ & 601 & 12.2 & 138 & 2.2 & 995 & 27.5 & 917 & 16.7 & 235 & 5.1 & 140 & 3.8 \\
\hline $\begin{array}{l}\text { Catho } \\
\text { lic }\end{array}$ & 363 & 7.4 & 443 & 6.9 & 18 & 0.5 & & & 14 & 0.3 & 11 & 0.3 \\
\hline $\begin{array}{c}\text { Musli } \\
\text { m }\end{array}$ & 407 & 8.3 & 189 & 3.0 & 24 & 0.6 & 11 & 0.2 & 7 & 0.2 & 5 & 0.1 \\
\hline $\begin{array}{c}\text { Mosai } \\
\text { c }\end{array}$ & 173 & 3.5 & 102 & 1.6 & & & & & & & & \\
\hline $\begin{array}{l}\text { Arme } \\
\text { nian }\end{array}$ & 444 & 9.0 & 21 & 0.3 & 14 & 0.4 & & & & & & \\
\hline Hindi & 4 & 0.1 & & & & & & & & & & \\
\hline $\begin{array}{l}\text { Evang } \\
\text { elical }\end{array}$ & & & 30 & 0.5 & & & & & & & & \\
\hline $\begin{array}{c}\text { Other } \\
\text { religio } \\
\text { ns }\end{array}$ & & & 18 & 0.2 & 17 & 0.5 & 24 & 0.5 & 5 & 0.1 & 3 & 0.1 \\
\hline $\begin{array}{l}\text { Unav } \\
\text { ailabl } \\
\text { e } \\
\text { infor } \\
\text { matio } \\
\text { n } \\
\end{array}$ & & & & & & & & & & & 153 & 4.2 \\
\hline Total & 4913 & 100 & 6399 & $\begin{array}{c}100 \\
\%\end{array}$ & 3622 & $\begin{array}{c}100 \\
\%\end{array}$ & 5484 & $\begin{array}{c}100 \\
\%\end{array}$ & 4601 & $\begin{array}{c}100 \\
\%\end{array}$ & 3663 & $\begin{array}{c}100 \\
\%\end{array}$ \\
\hline
\end{tabular}

${ }^{*}$ Given the lock of data, the calculations aredetermined indirectly by the ethnic belonging to various

confenssions

In the interwar period, within the Sulina town there were four Orthodox churches (two Romanian, one Russian and one Armenian), an Anglican church, an Orthodox church, a Protestant church, two mosques and a Jewish temple. Practically, there were nine places of worship. Currently, there still exist four Orthodox churches (two Romanian, one Greek and one Old Rite Russian) and one Catholic church (Fig. 3). 


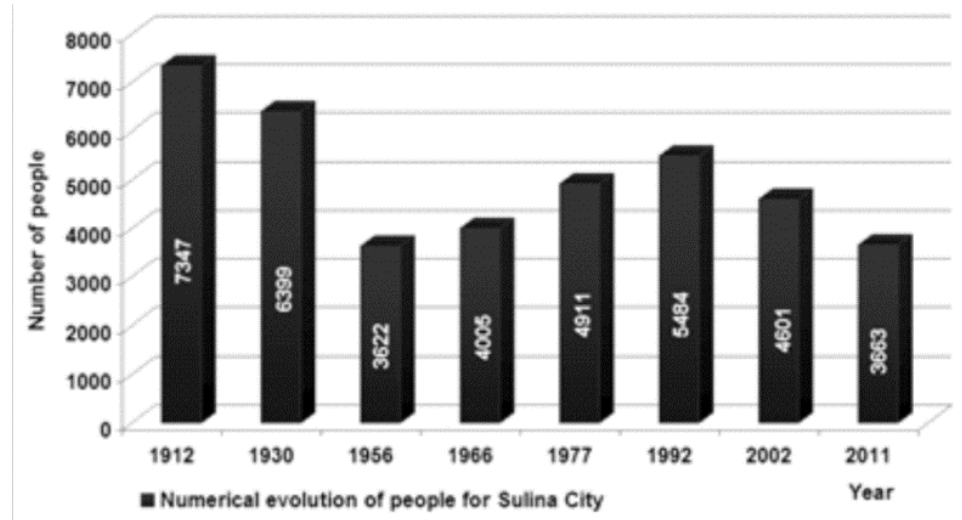

Fig. 2 Numerical evolution of the population of Sulina town

The consequence of a history of ethnic mosaic in the Sulina town is the existence of a multiethnic cemetery, categorized by population, as follows: Orthodox (Romanian, Greek, Old Rite Russian Lippovan), Jewish, Muslim (Turkish), Catholic (Italian) and that of the European Danube Commission (E.D.C.) (Fig. 4). The cemetery of Sulina could be part of the Guinness Book because it delimits distinct areas for certain ethnic groups united under the "commercial congregation" of the free port of Sulina. The cemetery includes three great confessions: Christian (the E.D.C. cemetery; the Orthodox cemetery; the Old Rite Orthodox cemetery; the cemetery of the Western European Churches); Muslim; Mosaic.

\section{DISCUSSIONS}

The flourishing economic development of the Sulina town was also stimulated by the constitution of the European Danube Commission (Treaty of Paris, 1856) and by the status of free port (porto franco). At that point, the political factor played a particular role in the ethnic and confessional diversification of the Sulina town. The construction of the Sulina channel and the dredging of the Danube mouths required skilled personnel from the Western countries. The right shore of the Danube was used for the headquarters of the European Danube Commission, while the left shore was used for shipyards and small enterprises (Fig. 5).

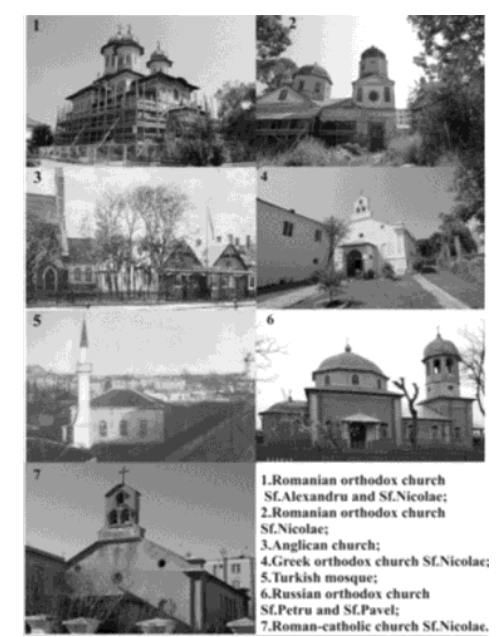

Fig. 3 Ancient and current churches in the Sulina town 
The consequence of a history of ethnic mosaic in the Sulina town is the existence of a multiethnic cemetery, categorized by population, as follows: Orthodox (Romanian, Greek, Old Rite Russian Lippovan), Jewish, Muslim (Turkish), Catholic (Italian) and that of the European Danube Commission (E.D.C.) (Fig. 4). The cemetery of Sulina could be part of the Guinness Book because it delimits distinct areas for certain ethnic groups united under the "commercial congregation" of the free port of Sulina. The cemetery includes three great confessions: Christian (the E.D.C. cemetery; the Orthodox cemetery; the Old Rite Orthodox cemetery; the cemetery of the Western European Churches); Muslim; Mosaic. After the dissolution of this commission, (1938) the fall of the Sulina town began. The dissolution of the European Danube Commission occurred on 18 August 1938 (The Agreement of Sinaia), when the Administration of Lower Danube was constituted, as a body controlled by the Romanian government. Hence, the transportation fees for the Sulina channel were taken over by the Administration of Lower Danube, with headquarter in Galați. The communist period tried to invigorate the area. Because of the geographic position favourable for commerce, the Sulina port acquired the status of porto franco in the year 1978, when the Administration of the Sulina Free Port was constituted. Subsequently, the Governmental Decision 156/22.04.1993 established the Administration of the Sulina Free Zone, with an autonomous administration regime, organized on the principles of economic and financial self-management. The Sulina Free Zone comprises 100.89 ha. The goods can be deposited in the free zone; furthermore, the raw materials can be processed, sorted out, marked, assembled, etc. The goods deposited and processed in the free zone can be delivered on the market. Unfortunately, this measure

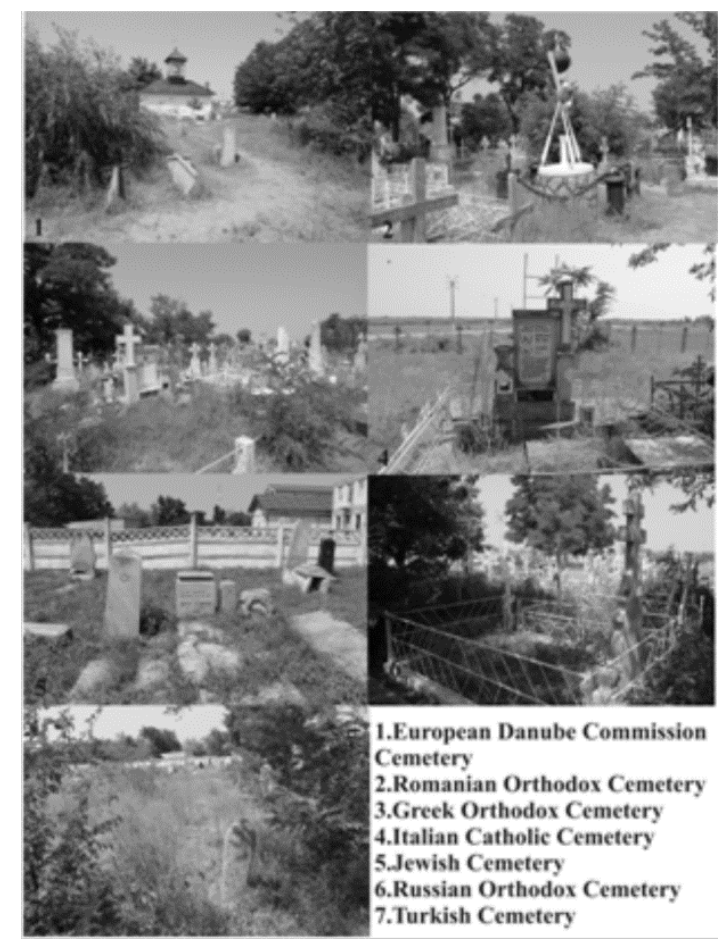

Fig. 4 Multiethnic cemetery of Sulina 


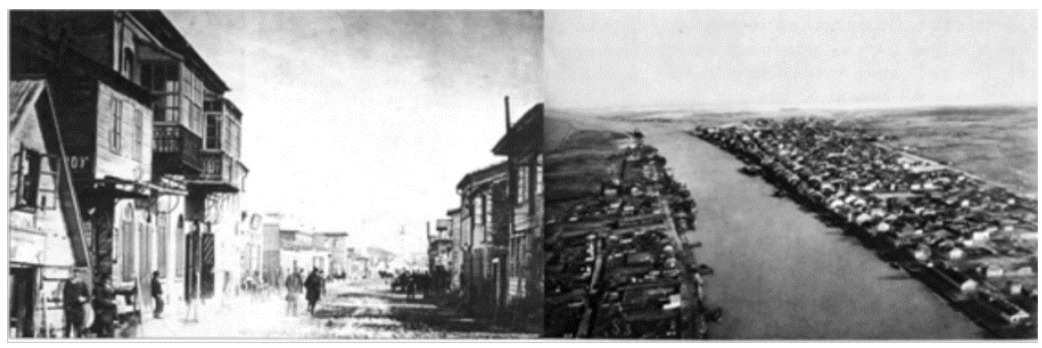

Fig. 5 Images of Sulina in 1890 (left) and 1930 (right)

determined only short-term advantages. Following the events of the winter of 1989, when the communist system collapsed, a new crisis emerged. Under these circumstances, the population of the town dropped compared to the end of the nineteenth century: 3,663 inhabitants in the year 2011 (Fig. 2). Currently, attempts have been made to invigorate the area by promoting littoral and deltaic tourism. Danube Delta is a Biosphere Reservation, the unique such morpho-hydrographic unit on Earth.

The great number of ethnic group, (22) mentioned at the end of the nineteenth century and in the year 1912, is also determined by the fact that most of them belonged to the countries that created the European Danube Commission. It is worth pinpointing the great number of Greeks (2,056) - 42.05\%, Armenians (444), Jews (173) and Albanians (117), who were prolific merchants and who had the monopole of grains or commercial units. The great number of Turks (268) was due to Dobrudja belonging to the Ottoman Empire (until the year 1878). The Lippovan Russians (546) and the Ukrainians came to the Danube Delta during the oppression of Empress Catherine II (1762-1796). They were totally integrated into the Ottoman Empire and then into the Romanian State because they were allowed to keep their religion. We find interesting the small number of Romanians (803), who represented only $16.42 \%$ in the year 1912 . Most Romanians came to Sulina following the annexation of Dobrudja, in the year 1878. The communist period - that encouraged the increase in the population of the Danube Delta - changed radically the ethnic structure of Sulina. Hence, in the entire area of the Danube Delta, Romanians are dominant (Tables 2, 3). Romanian have manifested their dominance starting with the census of $1930(47.2 \%)$ and they reached the climax in the year $2002(86 \%)$.

The total population of Sulina was completed by a number of employees of the European Danube Commission, foreigners with temporary residence at Sulina (Table 5). These employees came from England, Italy, Germany, Austria, France, etc.

Table 5 Employees of the European Danube Commission in the year 1930 (after the European Danube Commission, 1931)

\begin{tabular}{|c|c|c|c|c|c|c|}
\hline No. & Nationalities & $\begin{array}{c}\text { Table normal (part of } \\
\text { the management) }\end{array}$ & Pilots & $\begin{array}{c}\text { Intermediary } \\
\text { personnel }\end{array}$ & $\begin{array}{c}\text { Inferior } \\
\text { personnel }\end{array}$ & Total \\
\hline 1 & Germans & - & - & - & 1 & 1 \\
\hline 2 & English & 6 & 1 & 1 & 1 & 9 \\
\hline 3 & Armenians & 1 & - & - & 2 & 3 \\
\hline 4 & Belgians & 1 & - & - & - & 1 \\
\hline 5 & Danish & 1 & - & - & - & 1 \\
\hline 6 & French & 9 & 1 & - & - & 10 \\
\hline 7 & $\begin{array}{l}\text { French } \\
\text { Protégés }\end{array}$ & 1 & - & - & - & 1 \\
\hline 8 & Greeks & 3 & 10 & 9 & 33 & 55 \\
\hline 9 & Italians & 11 & 3 & 4 & 7 & 25 \\
\hline 10 & Turks & - & 7 & - & 6 & 13 \\
\hline 11 & Polish & 1 & - & - & - & 1 \\
\hline
\end{tabular}




\begin{tabular}{ccccccc}
12 & Romanians & 25 & 26 & 29 & 128 & 208 \\
13 & Russians & - & 1 & - & - & 1 \\
14 & Yugoslavians & 7 & 9 & 4 & 10 & 30 \\
Total & - & 66 & 58 & 47 & 188 & 359 \\
\hline
\end{tabular}

The ethnic groups - except for Romanians, Lippovan Russians, Ukrainians and Bulgarians - lived exclusively in the Sulina town (Table 6). The ethnic groups with tradition in the commercial life were attracted by the only town with European tradition in the Danube Delta. Skilled workers in certain technical fields were brought here for the shipyards. For the censuses of 1956, 1992 and 2002 no comparisons were made, because the European Commission no longer existed and because the economic fall of Sulina also made most ethnic groups leave the town.

Table 6 Comparison between the ethnic groups of Sulina and the Danube Delta in the year 1912

\begin{tabular}{cccc}
\hline No. & Nationalities & No. of inhabitants in Sulina & No. of inhabitants in the Danube Delta \\
\hline 1 & Greeks & 2056 & 2059 \\
2 & Romanians & 803 & 2652 \\
3 & Russians & 546 & 4303 \\
4 & Armenians & 444 & 444 \\
5 & Turks & 268 & 290 (Tatars included) \\
6 & Austro-Hungarians & 211 & 211 \\
7 & Jews & 173 & 173 \\
8 & Albanians & 117 & 117 \\
9 & Germans & 49 & 49 \\
10 & Italians & 45 & 45 \\
11 & Bulgarians & 35 & 103 \\
12 & English & 24 & 24 \\
13 & Tatars & 22 & See the Turks \\
14 & Montenegrins & 22 & 22 \\
15 & Serbians & 21 & $-*$ \\
16 & Polish & 17 & $-*$ \\
17 & French & 11 & 11 \\
18 & Lippovans & 7 & $-*$ \\
19 & Danish & 6 & $-*$ \\
20 & Gagauzians & 5 & $-*$ \\
21 & Indians & 4 & 12209 \\
22 & Egyptians & 3 & $*$ \\
Total & - & 4889 & $*$ For
\end{tabular}

The entire life of the town - unique in Romania also because the main streets, parallel with the Sulina arm, are numbered like in New York - unfolds around the Palace of the Administration of the European Danube Commission. This perimeter includes all the consular, customs, social, cultural, etc offices. This context led to the construction of the most important churches. They represented the religious orientation of the moment. On a couple of hundred square meters, there were five churches belonging to various confessions (Figs. 6, 7).

The history of the Sulina town - after the constitution of the European Danube Commission (1856) - does not include conflicts related to religious confession. Most "ethnic" conflicts were actually caused by economy, alcohol and love or gambling. Aggressive language or pub scandals were not ethnic or confessional conflicts. This was demonstrated by the entire history of the localities within the Danube Delta where Old Rite Russian Lippovans and Turks or Muslim Tatars lived alongside Orthodox 
Romanians. The delimitation of the cemetery space by religion demonstrates the existence of a harmonious cohabitation. In the cemetery, it is worth underlining the space destined to the European Danube Commission, where the officials who died at Sulina were buried. Most of them died because of typhoid fever or other viral diseases. The climate - mostly in the winter - was far too harsh for the employees of the European Danube Commission, who came from the Mediterranean countries.

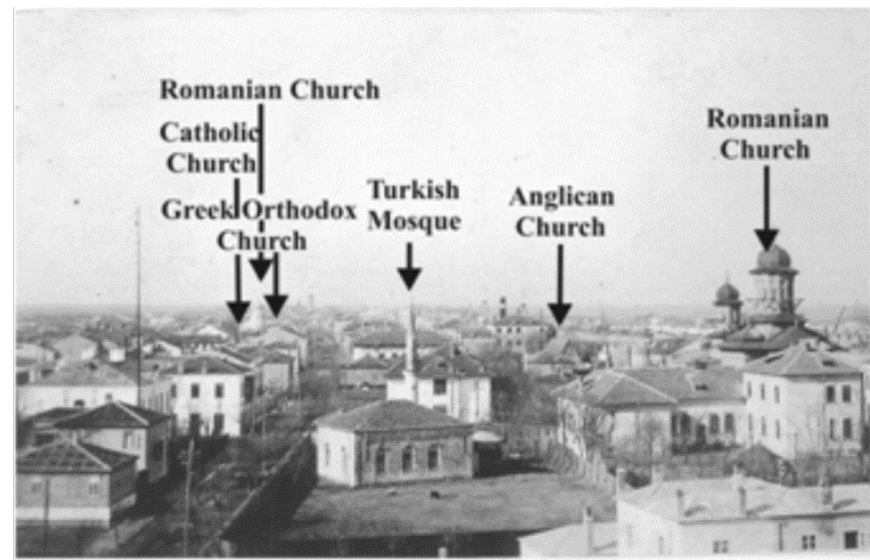

Fig. 6 Distribution of the five places of worship in the centre of the Sulina town

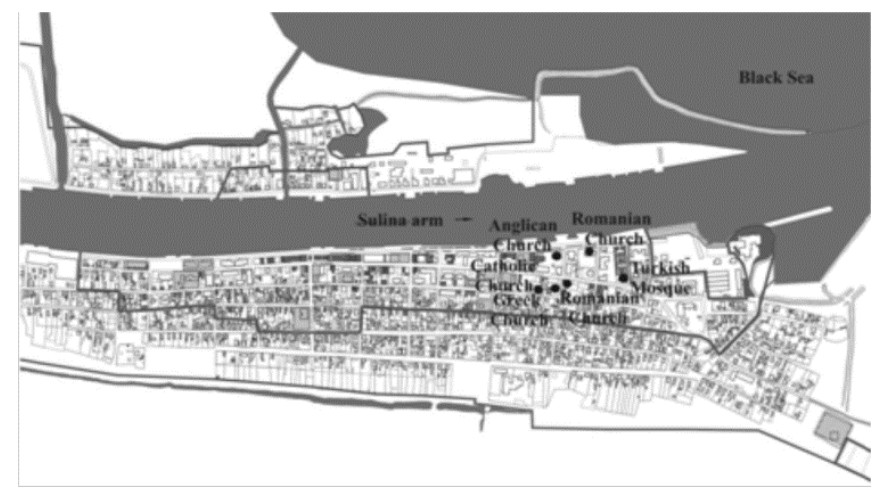

Fig. 7 Cadastral placement of the five places of worship in the Sulina town

The outbreak of the Second World War and the instauration of communism in Romania determined a dramatic drop in the number of inhabitants and the total disappearance of the employees of the European Danube Commission (Fig. 8). The economic fall of Romania - and of Sulina, implicitly - led to the mass immigration of the ethnic groups that dealt with commerce: Greeks, Jews and Armenians. The radical changes in the ethnic and religious structure in the Sulina town were mainly related to the economic and political issues. The constitution of the European Danube Commission and the economic boom recorded by the Romanian State in the interwar period - mostly in terms of grains (exported through the Sulina port) - led to a significant increase in the population of the Sulina town. The flourishing commerce and the status of porto franco attracted the most mobile ethnic groups from this perspective: Greeks, Jews, Armenians, Turks, etc.

Religion confessions preserved their number, but the minority ones decreased drastically, while the majority ones increased. The censuses of 1956, 1992, 2002 and 2011 did not mention the Mosaic, Armenian and Hindi confessions (Fig. 9). Numerous religious confessions were still present; however, the Orthodox Christians had multiplied vertiginously by the year 2011 . 

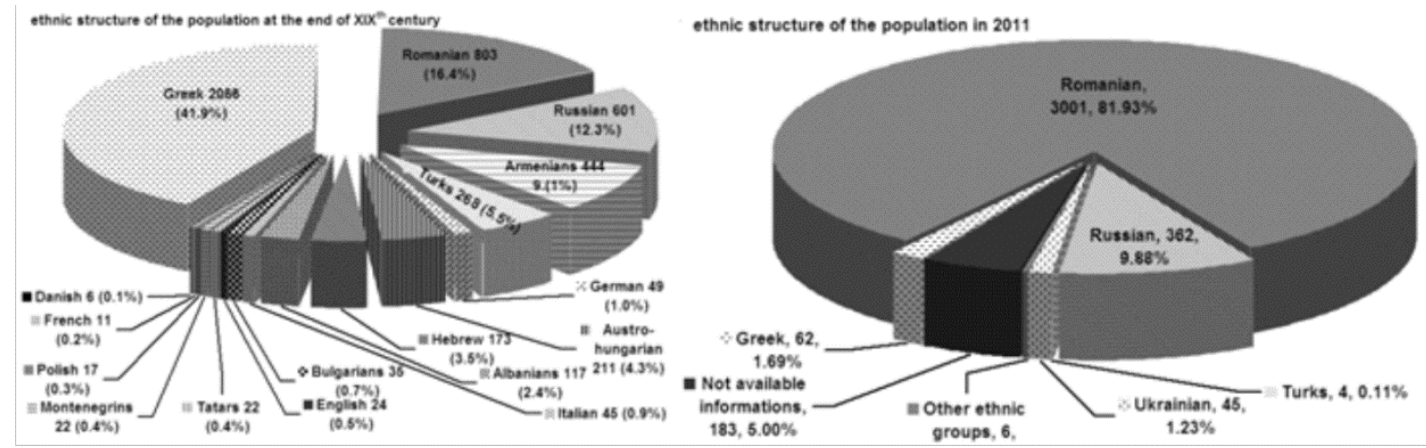

Fig. 8 Ethnic structure of the population of Sulina town

at the end of the nineteenth century and in the year 2011
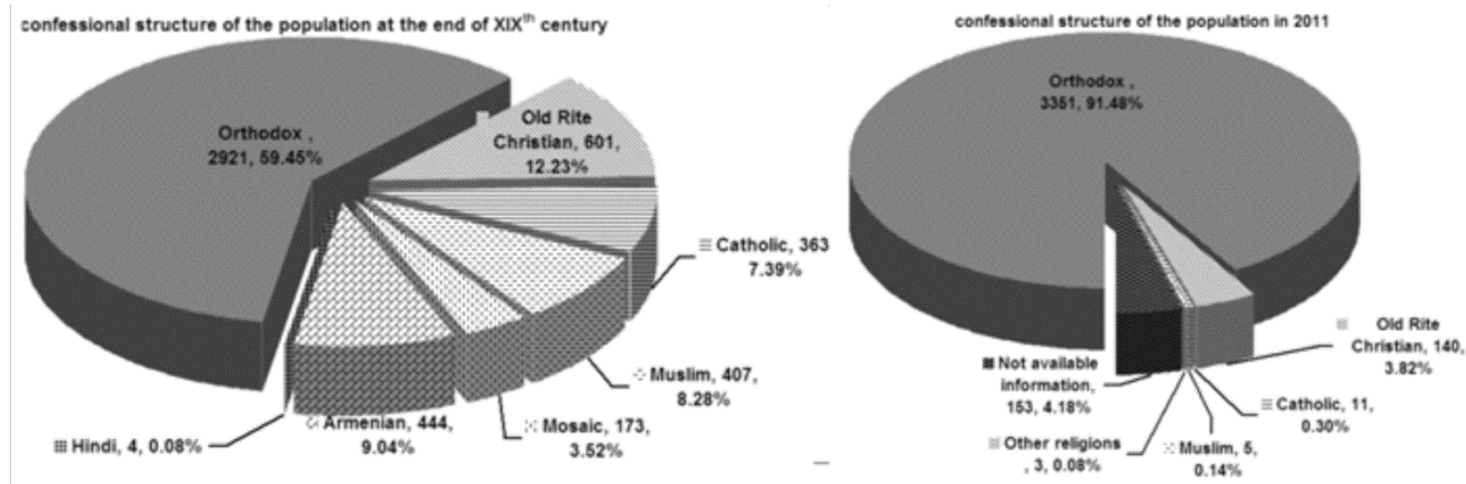

Fig. 9 Religious structure of the population of the Sulina town at the end of the nineteenth century and in the year 2011

\section{CONCLUSIONS}

The Sulina town represents the model of ethnic and religious cohabitation in Romania and in Europe, at the same time. The creation of the European Danube Commission determined an increase in the number of town's population and an impetuous economic development. This attracted a series of ethnic groups with commercial interests: Greeks, Jews, Turks, Armenians, Albanians, etc. The Lippovan Russians came because of the forced emigration determined by the political and religious factors in the Russia of Empress Catherine II.

Ethnic cohabitation was ensured by profit. At the same time, the European Danube Commission imposed rules that forced the population to keep the order. The nine consular institutions and the numerous European insurance companies favoured a peaceful cohabitation between the members of different religions: Orthodox, Old Rite Orthodox, Catholics, Mosaics, Protestants, Muslims, etc.

Of the churches on the territory of the Sulina town, only five still exist. The following were destroyed during the bombing raids of the Second World War: the Anglican church, the mosques, the synagogue and the Protestant church. Today, still stand tall two Romanian churches, an Old Rite Lipovan church, a Greek church and a Roman-Catholic one.

The outbreak of the Second World War and the dissolution of the European Danube Commission (1938) led to the economic fall of the Sulina town and to its gradual depopulation. The most interesting testimony of ethnic and confessional diversity is represented by the common cemetery. The cemetery precinct is delimited by ethnic and confessional communities and by the social status: Orthodox (Romanian, Greek), Old Rite Orthodox (Russian Lippovan and Ukrainian), Catholic (Italian), Muslim (Turkish), 
Mosaic (Jewish) and of the European Danube Commission (Catholic and Protestant). The town cemetery is a good example of "cohabitation" even after death. The cemetery of the European Danube Commission can be included in the National Patrimony as a monument of religious art. The cemetery as a whole can be declared art monument of European interest.

\section{ACKNOWLEDGMENTS}

This work was supported by the Partnership in Priority Domains project PN-II-PTPCCA-2013-4-2234 no. 314/2014 of the Romanian National Research Council, Nondestructive approaches to complex archaeological sites. An integrated applied research model for cultural heritage management - arheoinvest.uaic.ro/research/prospect.

\section{REFERENCES}

[1] Hiekel N., Liefbroer A.C. \& Poortman A.R. Unfderstanding Diversity in the Meaning of Cohabitation Across Europe. European Journal of Population. Doi:10.1007/s10680014-9321-1, 2014.

[2] Sosis R. Religion and Intragroup Cooperation: Preliminary Results of a Comparative Analysis of Utopia Communities. Cross-Cultural Research, 34(1), pp. 70-87, 2000.

[3] Covacef P. The lively cemetery of Sulina (in Romanian). Editura EX PONTO, Constanta, 2003.

[4] Damian N. \& Dumitrescu B. Sustainable development prospects for the Danube delta rural communities. Romanian Journal of Geography, 53(2), pp. 153-163, 2009.

[5] Dobraca L. La gestion des aires critiques: le delta du Danube entre isolement et réserve. MAPPEMONDE, 53, pp. 15-19, 1999.

[6] European Commission. Assessment of the status development and diversification of fisheries-dependent communities. Danube Delta case study report, Romania. Fish/2006/09.http://ec.europa.eu/fisheries/documentation/studies/regional_social_econo mic_impacts/danube_delta_en.pdf. (accessed on 10 February 2014), 2011.

[7] Teampau P. \& Van Assche K. Sulina, when there's water, there's no light. Memory and autobiography in a Romanian town. Identities, 7(1-2), pp. 33-70, 2009.

[8] National Censuses. Demographic statistics of Romania; Population of the Romanian Kingdom, following the census of 19 December 1912 (in Romanian). Bucharest, 1912.

[9] National Censuses. General census of the population and the households in Romania, of 29 December 1930. Second volume: nationality, mother tongue, religion (in Romanian). Bucharest: Printed at the Official Gazette, National Printing Office, 1930.

[10] National Censuses. Population census: 1956, 1969, 1980, 1994, 2003, 2012. Demographic structure of the population (in Romanian). Bucharest: General Direction of Statistics, 1956, 1969, 1980, 1994, 2003, 2012.

[11] Chestiunea Dunarei. The Danube issue. Acts and Documents (in Romanian). Bucharest: Ministry of Foreign Affairs, MDCCCLXXXIII, 1933.

[12] Commission Européenne du Danube. Commission Européenne du Danube - son oeuvre de 1856 à 1931. Paris, 1931. 
